\title{
Fettet vi aldri blir ferdig med
}

\section{Myndighetene vil ha oss til å redusere inntaket av mettet fett og heller øke inntaket av umettet fett. En ny studie stiller spørsmål ved grunnlaget for denne anbefalingen.}

En studie om betydningen av økt inntak av umettet fett for forekomsten av hjerte- og karsykdom, basert på et tidligere upublisert datasett fra Minnesota for perioden 1968-73, er nylig publisert i tidsskriftet $B M J(1)$. Studien ble opprinnelig gjennomført som en randomisert, kontrollert studie med over 9400 pasienter i alderen 20-97 år, innlagt på eldrehjem eller psykiatriske sykehus. Pasientene ble randomisert til enten et kosthold uten mettet fett og rikt på linolensyre, særlig fra maisolje, altså et økt inntak av umettet fett, eller et kosthold rikt på mettet fett. Pasientene ble fulgt opp i 41-56 måneder.

Økt inntak av umettet fett førte til signifikant reduksjon i serum-kolesterol sammenlig-

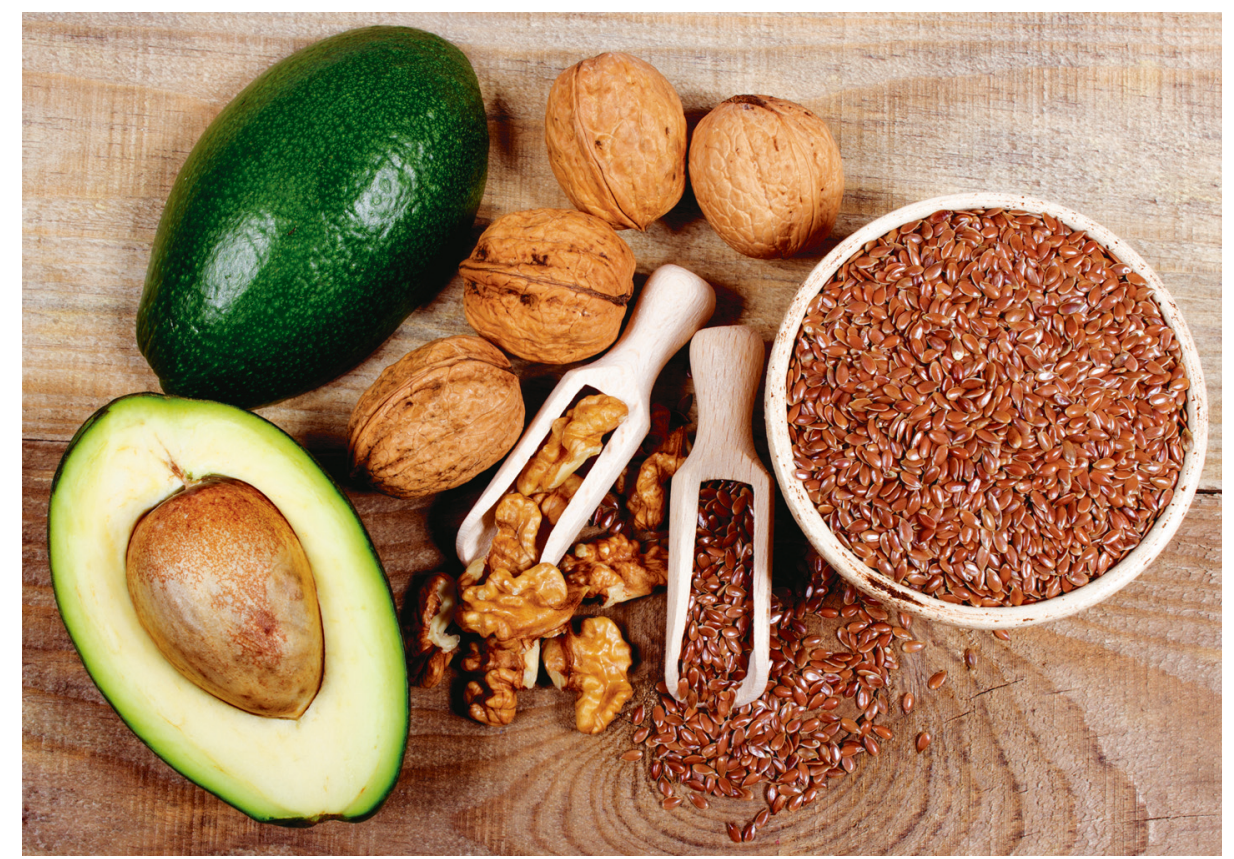

Illustrasjonsfoto: Thinkstock net med kosthold med mye mettet fett (henholdsvis $13,8 \%$ og $1,0 \%$ reduksjon fra utgangspunktet), men det var ingen forskjell i dødelighet mellom gruppene. For hver 0,78 $\mathrm{mmol} / \mathrm{l}$ reduksjon i kolesterol hadde begge gruppene analysert under ett $22 \%$ økt risiko for død (hasardratio 1,22; $95 \% \mathrm{KI} 1,14-1,32$ ). Forfatterne kommenterer at denne assosiasjonen synes å være drevet av populasjonen over 65 år. Økt inntak av umettet fett hadde ingen effekt på forekomst av hjerteinfarkt eller koronar aterosklerose, men obduksjonsrapporter for bare 149 av 517 pasienter som døde under studieperioden, ble analysert.

Forfatterne gjorde også et systematisk litteratursøk og en metaanalyse over randomiserte kontrollerte studier, der mettet fett ble erstattet med linolensyre og endepunktene var død pga. koronare hendelser eller totaldødelighet. Studier der man ga store mengder omega-3fettsyrer ble ekskludert. Det ble identifisert fem studier som omfattet flere enn 10800 personer. Analysen viste at økt inntak av umettet fett ikke ga en redusert totalmortalitet (HR 1,07; $95 \%$ KI $0,90-1,27)$ eller dødelighet relatert til koronare hendelser (HR 1,13; $95 \%$ KI 0,83-1,54).

- Hovedproblemet med denne studien er den korte gjennomsnittlige oppfølgingstiden, som ikke gjør den egnet til å si hvordan kosthold virker inn på risikoen for hjerte- og karsykdom, sier Vegard Lysne, som er klinisk ernæringsfysiolog og stipendiat ved Universitetet $\mathrm{i}$ Bergen. Intervensjonsdietten inneholdt dessuten mye høyere mengder flerumettet fett enn anbefalt $i$ dag, og ble bare gitt i form av omega- 6 .

- Det ble observert en assosiasjon mellom reduksjon av plasma-kolesterol og økt mortalitet blant de eldre deltagerne, men her er det ikke mulig å utelukke revers kausalitet, sier han. Reduksjonen i kolesterol kan også være en konsekvens av alvorlig sykdom. I tillegg frafalt rundt $75 \%$ av deltagerne i studien pga. en drastisk reduksjon $\mathrm{i}$ antallet sykehusplasser. Det kan ha betydd at man satt igjen med den sykeste delen av pasientmassen. Dessuten reduserte det studiens statistiske styrke, mener Lysne.

- I metaanalysen så de kun på studier som inkluderte omega- 6 , mens dagens anbefaling er å erstatte noe mettet fett med flerumettet fett, inkludert både omega-3 og -6, sier Lysne, som mener studien ikke rokker ved dagens kostholdsråd.

\section{Ketil Slagstad \\ Tidsskriftet}

Litteratur

1. Ramsden CE Zamora D, Majchrzak-Hong $\mathrm{S}$ et al. Re-evaluation of the traditional diet-heart hypothesis: analysis of recovered data from Minnesota Coronary Experiment (1968-73). BMJ 2016; 353: i1246. 